Article

\title{
Implementing Nature-Based Solutions in Rural Landscapes: Barriers Experienced in the PHUSICOS Project
}

\author{
Anders Solheim ${ }^{1, *}$, Vittoria Capobianco ${ }^{1}$ (D) Amy Oen ${ }^{1}$, Bjørn Kalsnes ${ }^{1}$, Turid Wullf-Knutsen ${ }^{2}$, Mari Olsen ${ }^{2}$, \\ Nicola Del Seppia ${ }^{3}$, Idoia Arauzo ${ }^{4}$, Eva Garcia Balaguer ${ }^{4}$ and James Michael Strout ${ }^{1}$ \\ 1 Norwegian Geotechnical Institute, P.O. Box 3930, N-0806 Oslo, Norway; vittoria.capobianco@ngi.no (V.C.); \\ ao@ngi.no (A.O.); bgk@ngi.no (B.K.); jms@ngi.no (J.M.S.) \\ 2 Innlandet County Administration, P.O. Box 4404, N-2325 Hamar, Norway; \\ turid.wulff.knutsen@innlandetfylke.no (T.W.-K.); mari.olsen@innlandetfylke.no (M.O.) \\ 3 Autorità di Bacino del Fiume Serchio (ADBS), Via Vittorio Veneto, 1, 55100 Lucca, Italy; \\ ndelseppia@gmail.com \\ 4 Consorcio de la Communauté de Travail des Pyrénées (CTP), Avenida Nuestra Senõra de la Victoria, 8 \\ 22700 Jaca, Spain; i.arauzo@ctp.org (I.A.); e.garcia@ctp.org (E.G.B.) \\ * Correspondence: anders.solheim@ngi.no; Tel.: +47-41653697
}

\section{check for} updates

Citation: Solheim, A.; Capobianco, V.; Oen, A.; Kalsnes, B.; Wullf-Knutsen, T.; Olsen, M.; Del Seppia, N.; Arauzo, I.; Garcia Balaguer, E.; Strout, J.M. Implementing Nature-Based Solutions in Rural Landscapes: Barriers Experienced in the PHUSICOS Project. Sustainability 2021, 13, 1461. https://doi.org/ $10.3390 /$ su13031461

Academic Editor: Gerd Lupp

Received: 13 December 2020

Accepted: 26 January 2021

Published: 30 January 2021

Publisher's Note: MDPI stays neutral with regard to jurisdictional claims in published maps and institutional affiliations.

Copyright: (c) 2021 by the authors. Licensee MDPI, Basel, Switzerland. This article is an open access article distributed under the terms and conditions of the Creative Commons Attribution (CC BY) license (https:// creativecommons.org/licenses/by/ $4.0 /)$.
Abstract: Nature-based solutions (NBS) are becoming increasingly important in both the EU and individual countries' political agendas, as a sustainable means to reduce the risk posed by hydrometeorological hazards. However, as the use of NBS is increasing, a number of barriers regarding their practical implementation also become apparent. A number of review studies have summarized and classified barriers, mainly in urban settings. PHUSICOS is a Horizon 2020 Innovation Action to demonstrate the use of NBS in rural and mountain landscapes. Large-scale demonstrator case sites with several sub-projects are established in Italy, Norway and in the French and Spanish Pyrenees. The present paper describes the project's NBS measures and their experienced barriers, some of which have resulted in full cancellation of the planned interventions. Many of the barriers experienced in rural settings have the same root causes as the ones described from urban areas, and the main barrier-creating mechanisms are institutional factors, resistance among stakeholders and technical and economic issues. The key element, however, is the lack of knowledge about the ability of NBS to deliver a series of co-benefits in addition to their risk-reducing effects and that long-term thinking is required to see the effect of many of these co-benefits.

Keywords: nature-based solutions (NBS); hydrometeorological hazards; PHUSICOS project; implementation barriers; flooding; landslides; avalanches; rockfall; Europe

\section{Introduction}

Nature-based solutions (NBS) is a collective term for solutions that are based on natural processes and ecosystems to solve different types of societal challenges. Of particular interest in the present study are adaptation strategies to reduce the risk from hydrometeorological hazards, such as landslides and floods. Although a wide range of definitions of NBS exist, as identified by Sarabi et al. [1], the European Commission's (EC) current definition is the presiding definition applied in the present study [2], "Solutions that are inspired and supported by nature, which are cost-effective, simultaneously provide environmental, social and economic benefits and help build resilience. Such solutions bring more, and more diverse, nature and natural features and processes into cities, landscapes and seascapes, through locally adapted, resource-efficient and systemic interventions". After the last report from the Intergovernmental Science-Policy Platform on Biodiversity and Ecosystem Services (IPBES), the following sentence has been added to the EC definition: "Nature-based solutions must therefore benefit biodiversity and support the delivery of a range of ecosystem services" [3]. An important aspect of NBS therefore is that they, in addition to reducing risk from natural hazards, can also deliver multiple other benefits [4]. 
These can be environmental (e.g., enhancing biodiversity), social (e.g., creating green space, enhancing esthetics and increasing inhabitants' well-being) or economic (e.g., affecting property prices in a positive way, or creating green jobs in the region).

The present study is part of the project PHUSICOS ("According to nature", in Greek), funded by the European Commission under the Horizon 2020 program. The five-year project (May 2018-April 2023) is an Innovation Action, with the objective of demonstrating the effectiveness of NBS and their ability to reduce the impacts from small, frequent events (extensive risks) in rural mountain landscapes. Nature-based solutions are cost-effective and sustainable measures inspired by nature that attenuate, and in some cases prevent, the impacts of natural hazard events and thereby the risks that affect the exposed regions. An important aspect of PHUSICOS is also the upscaling potential of the measures to be implemented. The novelty of the PHUSICOS project, and hence of the present study of implementation barriers, is that it focuses on rural mountain landscapes, whereas the majority of NBS studies are from urban settings.

The NBS to be implemented and evaluated in PHUSICOS are based on modifying the vegetation cover and/or managing the excessive amount of surface water runoff during extreme events at demonstrator sites in rural landscapes throughout Europe. The successful implementation of such measures would not only reduce the risk to the local population but will also prevent the accumulated impacts of small events from becoming large-scale disasters (intensive risks) in densely populated urban areas downstream and far away from the source of hazard. Furthermore, many transportation routes, lifelines and critical infrastructure that are essential for society pass through rural and mountainous areas and their functionality is threatened by landslides and floods triggered by hydrometeorological events.

Research and evidence-based examples are still important to document that NBS are effective at larger scales [5], which is necessary information to enable changes in policies and practices and to make NBS become mainstream solutions. A first global systematic mapping of the effectiveness of nature-based interventions for addressing the impacts of climate change and hydrometeorological hazards was published by Chausson et al. [6]. The authors concluded that there is a lack of robust, site-specific investigations of the effectiveness of interventions compared to traditional alternatives and such site-specific evidence is needed to support the political shift towards employing NBS. In addition to this lack of evidence, there are also several barriers, ranging from technical (i.e., design, planning) to those of a practical character, that need to be considered when implementing NBS. Recent studies have also highlighted that main barriers hampering the proliferation of NBS in urban environments are mostly policy barriers, but that they are also contextand place-specific [7].

While the objective of the PHUSICOS project is to demonstrate the effectiveness and upscaling potential of NBS interventions in rural landscapes, the objectives of this paper are to present a selection of NBS that are slated for implementation at several European case study sites as well as to present and subsequently discuss barriers experienced for the practical implementation of these. The framing of this study in the perspective of barriers is intentional to show the negative impact these have on the implementation of NBS. This is summarized in the final section of the paper. Although problems are inevitable and new challenges will appear, the intention of sharing experiences and discussing how problems can be avoided is to reduce such barriers for NBS projects to come.

\section{Materials and Methods}

PHUSICOS includes three large-scale demonstrator sites to demonstrate the functionality of NBS for reducing the risk from natural hazards. The large-scale demonstrator sites are located in the valley of Gudbrandsdalen in Norway, in the Pyrenees of France and Spain and in the Serchio River Basin in Italy (Table 1, Figure 1). The hazards comprise snow avalanches, landslides, rock fall, flooding and erosion. In addition, the Italian demonstrator site also deals with runoff from agricultural areas and therefore includes spreading of 
pollutants. In addition, the project includes two smaller concept case sites: the Isar river in Munich [8], Germany, and the Kaunertal valley in Austria [9]. The former is a "retrogressive case" from which the PHUSICOS project intends to learn from its experiences, particularly regarding stakeholder involvement. The latter is an experimental case to use bacteria-enhanced growth to stabilize barren slopes exposed in front of a rapidly retreating glacier. Further details of these two concept cases are not discussed in the paper, as they are less relevant regarding the discussion of implementation barriers, being the main focus of this paper.

Table 1. Overview of nature-based solutions (NBS) interventions in the PHUSICOS project. CC: concept case sites. Status in mid-November 2020.

\begin{tabular}{|c|c|c|c|c|}
\hline Site & Proposal & Hazard & Type Intervention & Status \\
\hline Gudbrandsdalen, Norway & G1: Jorekstad & Flooding & $\begin{array}{l}\text { Use of flood plain; } \\
\text { receded green barrier }\end{array}$ & $\begin{array}{l}\text { Approved, may be } \\
\text { cancelled }\end{array}$ \\
\hline Gudbrandsdalen, Norway & G2: Skurdalsåa & Flooding & $\begin{array}{l}\text { Retention high in } \\
\text { catchment }\end{array}$ & $\begin{array}{l}\text { Not yer formally } \\
\text { proposed }\end{array}$ \\
\hline Serchio River Basin, Italy & $\begin{array}{l}\text { SRB-A: Canals by } \\
\text { Lake Massaciuccoli }\end{array}$ & $\begin{array}{l}\text { Erosion, run-off, } \\
\text { pollution }\end{array}$ & Vegetated buffer strips & $\begin{array}{l}\text { Approved, } \\
\text { implemented }\end{array}$ \\
\hline Serchio River Basin, Italy & $\begin{array}{l}\text { SRB-B: Canals by } \\
\text { Lake Massaciuccoli }\end{array}$ & $\begin{array}{l}\text { Erosion, run-off, } \\
\text { pollution }\end{array}$ & Vegetated buffer strips & $\begin{array}{c}\text { Approved, } \\
\text { implemented }\end{array}$ \\
\hline Serchio River Basin, Italy & $\begin{array}{l}\text { SRB-C: Dam by Lake } \\
\text { Massaciuccoli }\end{array}$ & $\begin{array}{l}\text { Erosion, run-off, } \\
\text { pollutionErosion, } \\
\text { run-off, pollution }\end{array}$ & Vegetated pond & Approved \\
\hline Serchio River Basin, Italy & SRB-D: NBS Lab & $\mathrm{N} / \mathrm{A}$ & Educational & Approved \\
\hline Pyrenees, Spain & P1: Santa Elena & $\begin{array}{l}\text { Erosion, rockfall, } \\
\quad \text { instability }\end{array}$ & Vegetated terraces & Approved \\
\hline Pyrenees, France & P2: Socques & Torrents & $\begin{array}{l}\text { Reduce torrent energy by } \\
\text { wooden check dams }\end{array}$ & Cancelled \\
\hline Pyrenees, France & P3: Artouste & Rockfall & $\begin{array}{c}\text { Wood structures to } \\
\text { prevent release and } \\
\text { acceleration }\end{array}$ & Approved \\
\hline Pyrenees, France & P4: Bastan River & Flooding, torrents & $\begin{array}{l}\text { Change of river long \& } \\
\text { tranverse profile; allow } \\
\text { more room for floods }\end{array}$ & Cancelled \\
\hline Pyrenees, France & P5: Capet Forest & Snow avalanches & $\begin{array}{l}\text { Afforestation in release } \\
\text { area }\end{array}$ & $\begin{array}{l}\text { Approved, under } \\
\text { implementation }\end{array}$ \\
\hline CC-Isar River, Germany & Educational & Flooding & Flood plain restoration & Implemented \\
\hline CC-Kaunertal, Austria & Revegetation & Erosion, landslides & $\begin{array}{l}\text { Microbe-assisted } \\
\text { revegetation }\end{array}$ & $\begin{array}{c}\text { Under } \\
\text { implementation }\end{array}$ \\
\hline
\end{tabular}

NBS interventions funded by the PHUSICOS project are selected and approved using an evaluation procedure. The evaluation also includes a requirement of at least $40 \%$ funding from other sources than the project's EU funds. The procedure and the criteria upon which each proposal is evaluated are presented in the flowchart in Figure 2. 


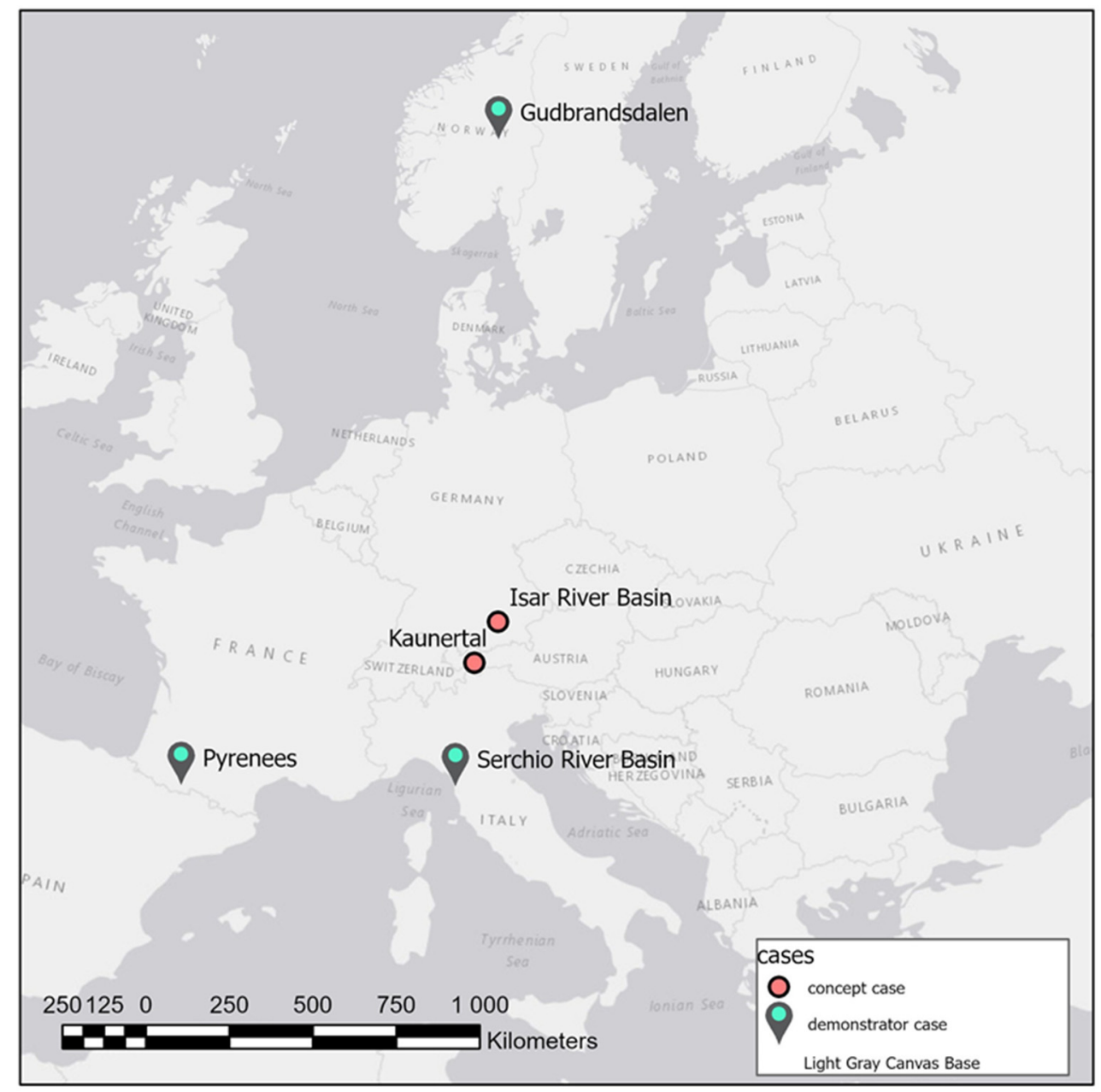

Figure 1. The three demonstrator sites (blue) and the two concept case sites (red) in PHUSICOS.

The evaluation process assesses a range of parameters that reflect the requirements of NBS including effectiveness, co-benefits and stakeholder involvement as well as risk reduction which is a key parameter for PHUSICOS. Assessing potential negative impacts is also part of the evaluation (see $[10,11]$ for details). The implementation barriers are predominantly present in Phase 5 of the evaluation process (Figure 2), and thus this paper will focus on this phase only and the other phases of the evaluation processes will not be discussed in further detail.

Regarding the barriers discussed in Chapter 3.2, we used all examples of barriers experienced in the PHUSICOS project until now, as it is important to share and learn from these experiences. On the other hand, this also, to some degree, puts a limitation on the width of the study. Furthermore, the procedure for the selection and approval of sites for NBS implementation is developed in the PHUSICOS project only and is so far not compared with other related projects. To reduce time and ensure progress in the site selection, only a semi-quantitative approach was carried out (Figure 2), whereas a full multi-criteria analysis could have been performed. However, as the focus of this study is the experienced barriers, the site selection process will not be described further in the present paper. 


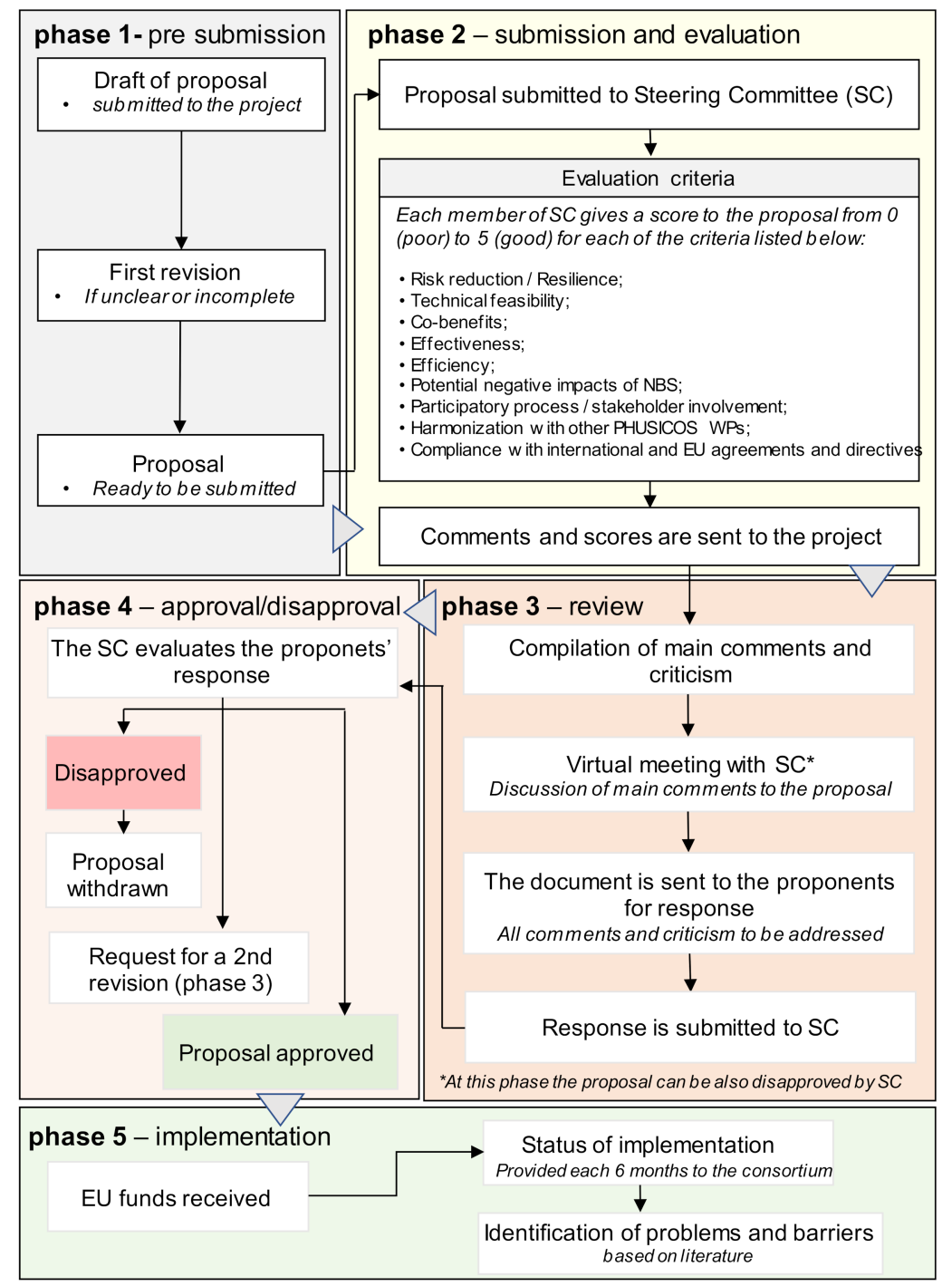

Figure 2. Flowchart showing the proposal approval process established in the PHUSICOS project.

\section{Results}

For each of the demonstrator case study sites, the NBS interventions which have been proposed by the site owners and subsequently approved by the PHUSICOS Steering Committee (Phase 5 of Figure 2) are briefly described below. Some selected comments and concerns from the Steering Committee are presented for the respective demonstrator sites as these add to the discussion of barriers and to the "lessons learned" from the PHUSICOS project.

\subsection{PHUSICOS NBS Interventions}

\subsubsection{Gudbrandsdalen, Norway}

The first planned NBS intervention in the valley of Gudbrandsdalen is located on private land at Jorekstad in the Lillehammer municipality in south-eastern Norway (G1 in Figure 3) and comprises a receded flood barrier along the lower reaches of the river Gausa, which is a tributary river to the main river of Gudbrandsdalslågen. The confluence area between the two rivers has repeatedly experienced problems during floods [12]. This poses a threat to local infrastructure, farms and housing. Furthermore, eroded sediments from Gausa deposit in the confluence zone, changing the river bottom configuration and thereby enhancing the flood problems. The measure is meant to provide an area enough to reduce the energy of the river Gausa before it enters the main river. At the same time, agricultural land, farms and sports facilities are protected (Figure 4). The flood plain along Gausa has 
a riparian forest with several endangered species and is defined as an area of particular value for biodiversity by the Norwegian Environment Agency [13], who also, in fact, recommend that the existing flood barrier along the river is moved to outside of the forest to re-establish natural floodplain processes. The area consists of private land and is located in the Lillehammer municipality.

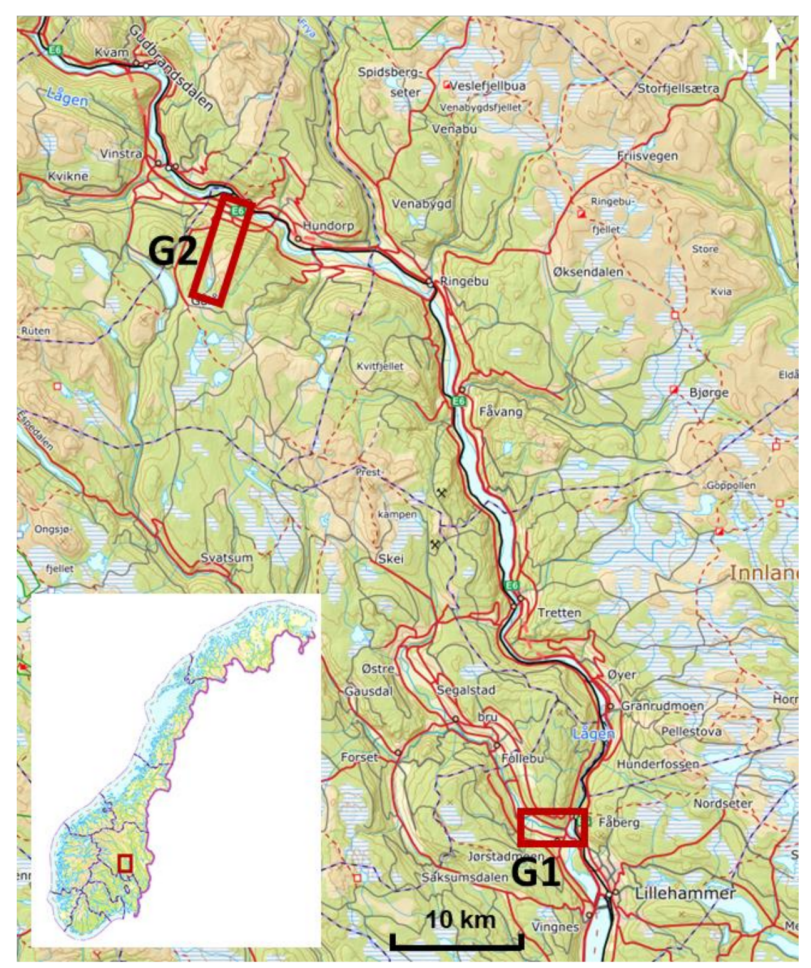

Figure 3. Location of the valley of Gudbrandsdalen, Norway. The city of Lillehammer is in the lower right corner. Locations are marked with red rectangles: G1: Jorekstad, G2: Skurdalsåa.

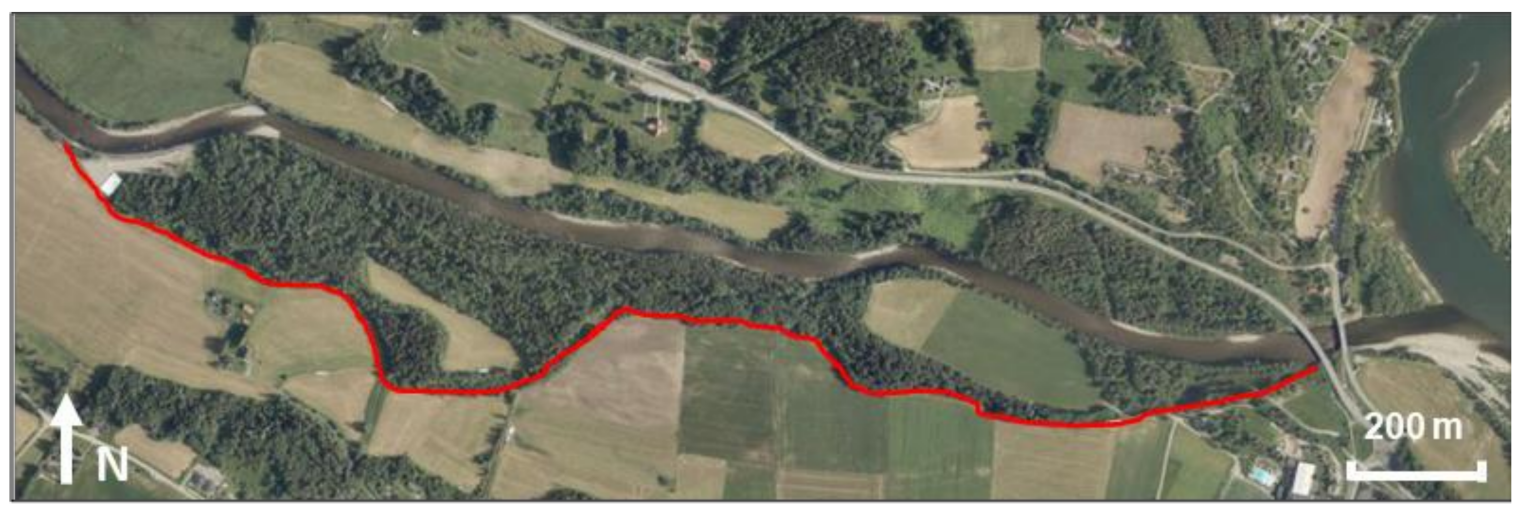

Figure 4. The lower reaches of the river Gausa, where it enters the main river Gudbrandsdalslågen (far right). The proposed receded flood barrier (Location G1 in Figure 3) is marked with red. The original flood barrier follows the southern riverbank.

Comments and concerns raised by the Steering Committee during the evaluation of the proposal comprised technical characteristics of the barrier, its height, shape, building material and esthetics, as well as its protective capabilities details from hydraulic modeling. However, questions were also raised about the estimated cost (which seemed low) and on the prognosed timeline (which seemed short for such a large project) during the public procurement process. Another question was regarding the level of detail in the participatory process and if the involved stakeholders had been sufficiently involved. 
Another potential NBS intervention under consideration for the Norwegian case study site is the re-utilization of old dams for flood retention (Figure 5). This intervention is located in the Nord-Fron municipality further north in the valley and approximately $65 \mathrm{~km}$ from the Jorekstad site (G2 in Figure 3). The river Skurdalsåa is a relatively small tributary river to the main river Gudbrandsdalslågen in the middle part of the Gudbrandsdalen valley. The river responds rapidly to precipitation and infrastructure in the lower reaches has experienced severe flood problems. Small lakes in the upper part of the catchment were dammed up in the late part of the 19th century to secure water for both consumption and for irrigation for the farms down in the valley. The measure to be proposed consists of re-establishing the function of the dam in one of these lakes by adding $0.5-1.0 \mathrm{~m}$ to its height and securing proper spillways. Estimates indicate that the measure may delay flooding downstream by 1-2 days, enough to take necessary precautions.

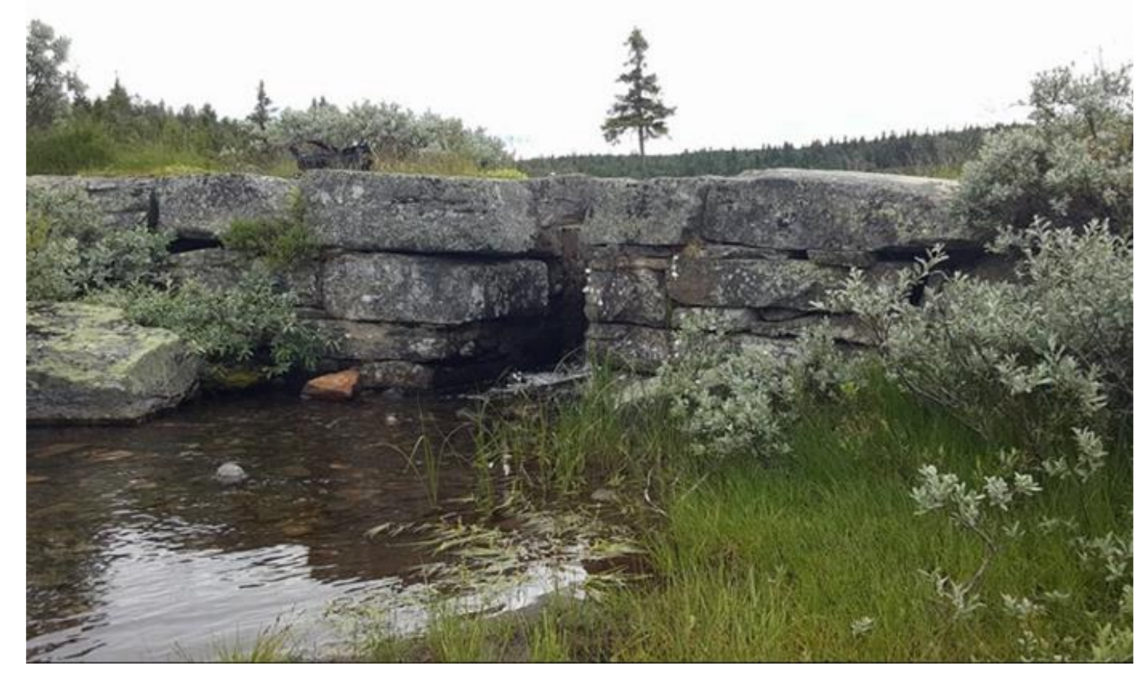

Figure 5. The old (>100 years) dam in the catchment of river Skurdalsåa (Location G2 in Figure 3). The height of the dam will be increased by $0.5-1.0 \mathrm{~m}$, but the appearance will remain (photo: "Skurdalsåas venner").

The main concern for this measure is that it will have to be approved by the Norwegian authority for energy and water resources, with a possibility that this may trigger a set of actions and increased costs, with the potential consequence that the intervention is no longer feasible. This intervention has still not been formally proposed to the project's Steering Committee.

\subsubsection{Serchio River Basin, Italy.}

The PHUSICOS NBS interventions to be implemented in Italy are located in private land near Lake Massaciuccoli in the region of Tuscany (Figure 6) and are focused on reducing runoff from farmland, with erosion and transport of sediments and pollutants to the aquatic environment [14]. The area is located south-east of Lake Massaciuccoli, a lake roughly at sea level, whereas the areas for the NBS are 1-2 m below sea level and kept dry by a system of pumping stations. The lake is polluted by the surrounding farmland. The lake is connected to the ocean through waterways and locks, but during times of drought, the locks cannot prevent influxes of sea water, resulting in very high salinity in the lake. The NBS interventions are intended to supplement an engineering solution to ensure a freshwater supply from the Serchio river during dry periods. 


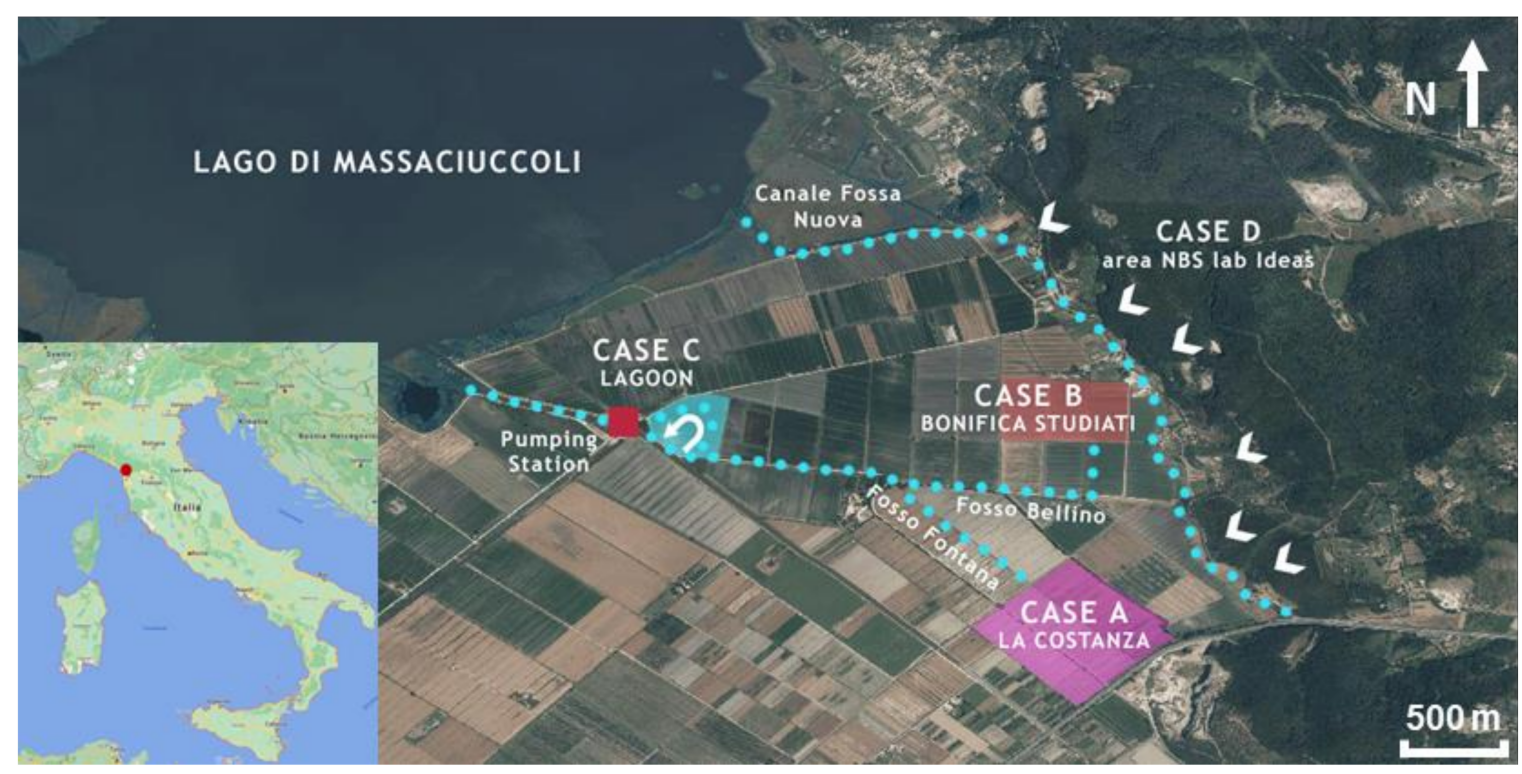

Figure 6. The area for NBS interventions by Lake Massaciuccoli. Buffer strips are being implemented in "Case A" and "Case $\mathrm{B}^{\prime}$, whereas the retention and sedimentation dam is planned at the location of "Case C". "Case D" denotes a suggested learning platform for NBS at the local and regional levels. The slope where it is marked is prone to shallow landslides (white marks) (illustration by Autorità di Bacino del Fiume Serchio-ADBS).

The measures to be implemented consist of a system of vegetated buffer strips along canals in two specified areas (Figures 6 and 7) with different soil conditions. The main crops in these areas are corn, sunflower and wheat, and the species seeded in the grassy buffer strips consist of Festuca arundinacea, Lolium perennis, Trifolium repens and Trifolium subterraneum. These are all native species and are seeded in buffer strip areas, but in somewhat different relative percentages based on the soil conditions of the two areas. The water from these areas will be led through a sedimentation basin with Phragmites australis and Thypha latifolia for further sedimentation and filtering of pollutants before the water is eventually led through the pumping system and supplied to the lake. This intervention is currently in the planning stage. The most affected stakeholders are the local farmers who are also the landowners. The area receives a high number of tourists and is popular for hiking and biking activities.

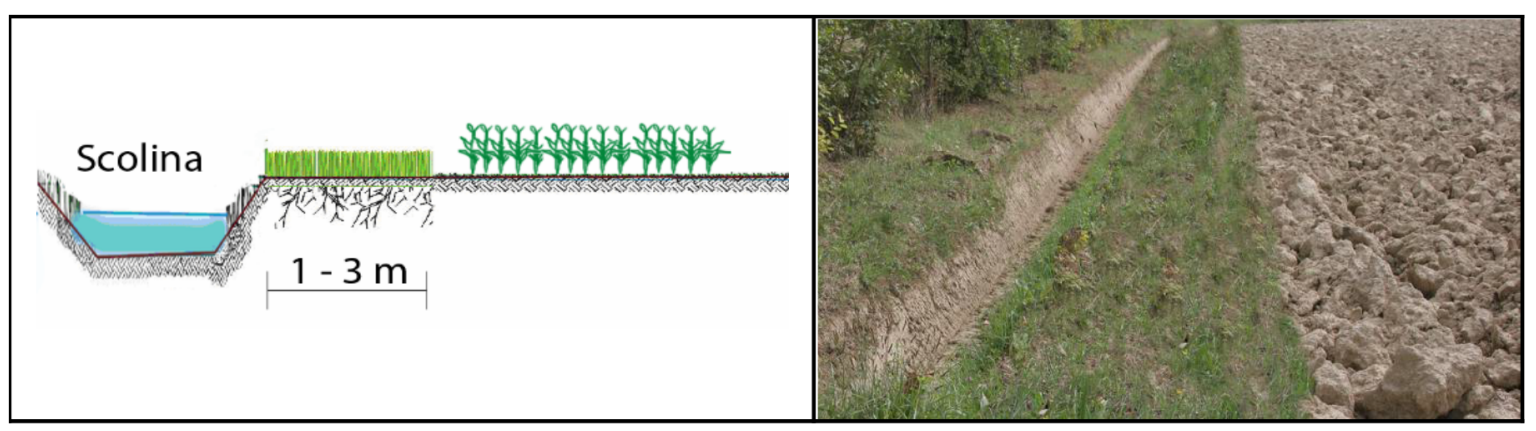

Figure 7. Sketch and example of the vegetated buffer strips being implemented along irrigation canals (illustration by Autorità di Bacino del Fiume Serchio-ADBS).

The evaluation process yielded high scores for feasibility and efficiency for the interventions. Main comments were related to the width of the buffer strips, the plants to be used, the relatively small size of the total area affected by the system of buffer strips and the sedimentation basin, the long-term maintenance and the level of risk reduction. 
However, concerns were also expressed regarding the needed agreement with the farmers to provide land and the cost of potential compensation or expropriation of land.

\subsubsection{The Pyrenees, France and Spain}

Five separate NBS interventions in the French and Spanish Pyrenees have been proposed and approved by the PHUSICOS Steering Committee. Three of the proposed interventions are located at sites along the same highly trafficked road between France and Spain, whereas the two others are located further to the east in the Bastan valley (Figure 8). The site owners are the proponents for the interventions in the Pyrenees and they represent three different regional organizations.

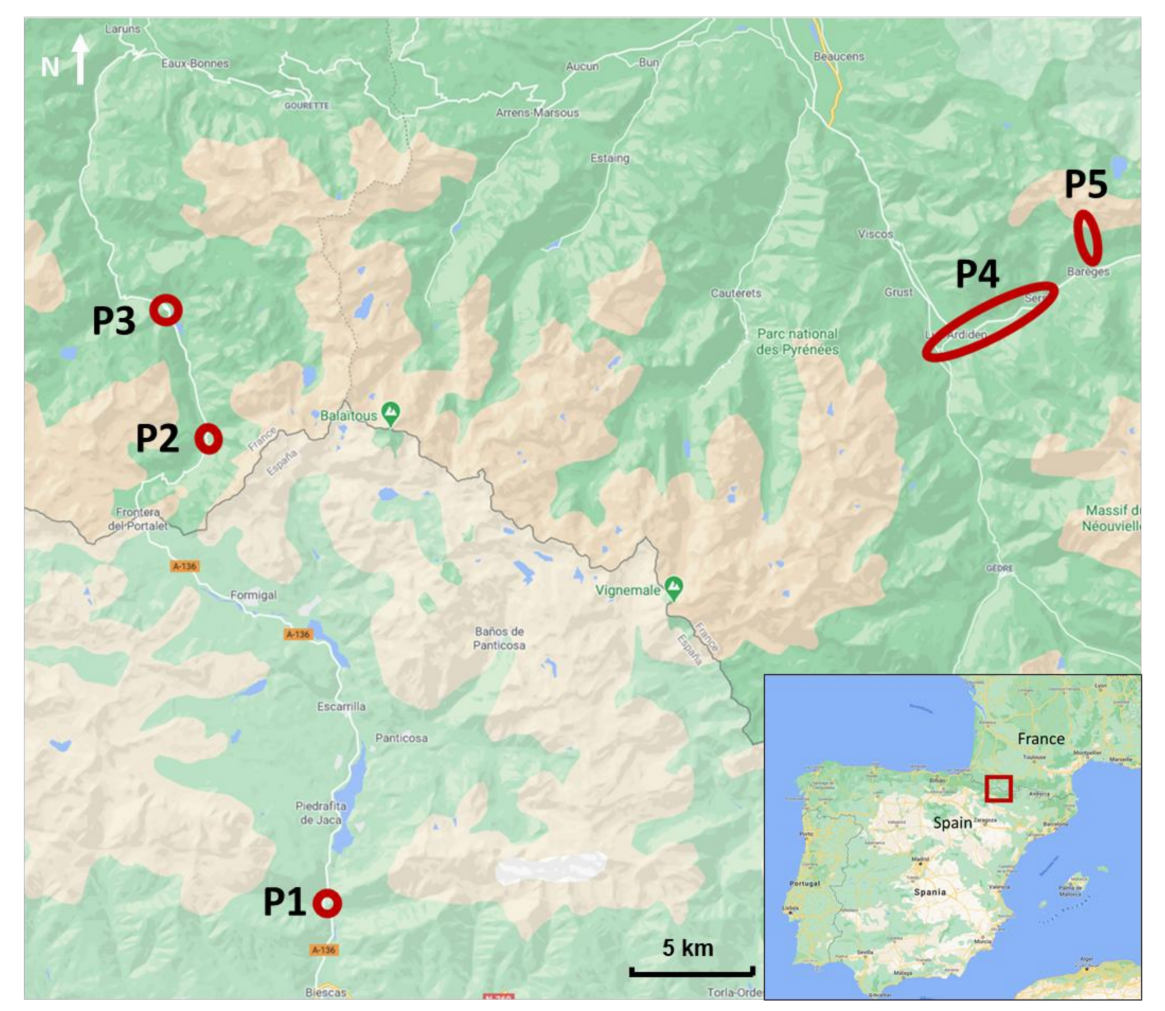

Figure 8. Location of the PHUSICOS sites in the Pyrenees. Sites for proposed and approved NBS interventions are marked P1-P5, where P1 is the case in Santa Elena, P2 is the case in Soques, P3 is the case in Artouste, P4 is the case in Bastan valley and P5 is the forest of Capet.

The three sites (P1, P2 and P3 in Figure 8) along the trans-border road A-136 (Spanish side)/RD-934 (French side) were all proposed by the "European Grouping of Territorial Cooperation-EGTC Space Portalet".

The site at Santa Elena, Spain (P1 in Figure 8), is located in the municipality of Biescas. The road A-136 passes a large end moraine ridge and faces significant problems of erosion and resulting rockfalls from the steep slope of the ridge (Figure 9). The location has been identified as a point of high risk in a consultant report mainly because of the limited visibility along the curved road and the high potential for fallen rocks or debris on the road. The measure to be implemented consists of terracing and re-vegetation of the slope, since it has been proven that roots can improve hydro-mechanical properties of soils [15-17]. The measures will also include solutions for drainage of the terraces and careful selection of plants to ensure the best stabilizing properties and not introducing alien species. The proposed measure will also require some engineered portions and may therefore be classified as a hybrid solution. A similar type of measure at a much larger scale was completed in 1905, stabilizing a whole valley side north of the village of Biescas. This slope has not had problems since, and from a distance, the measures are currently 
seen only as a forested hillside. The proposed measures at St. Elena are thus not new and innovative but are rather "re-discovering" techniques used in this region more than 100 years ago. Most comments from the Steering Committee during the evaluation process were concerning the technical details of the measure. It was considered feasible in the proposed time interval for implementation.
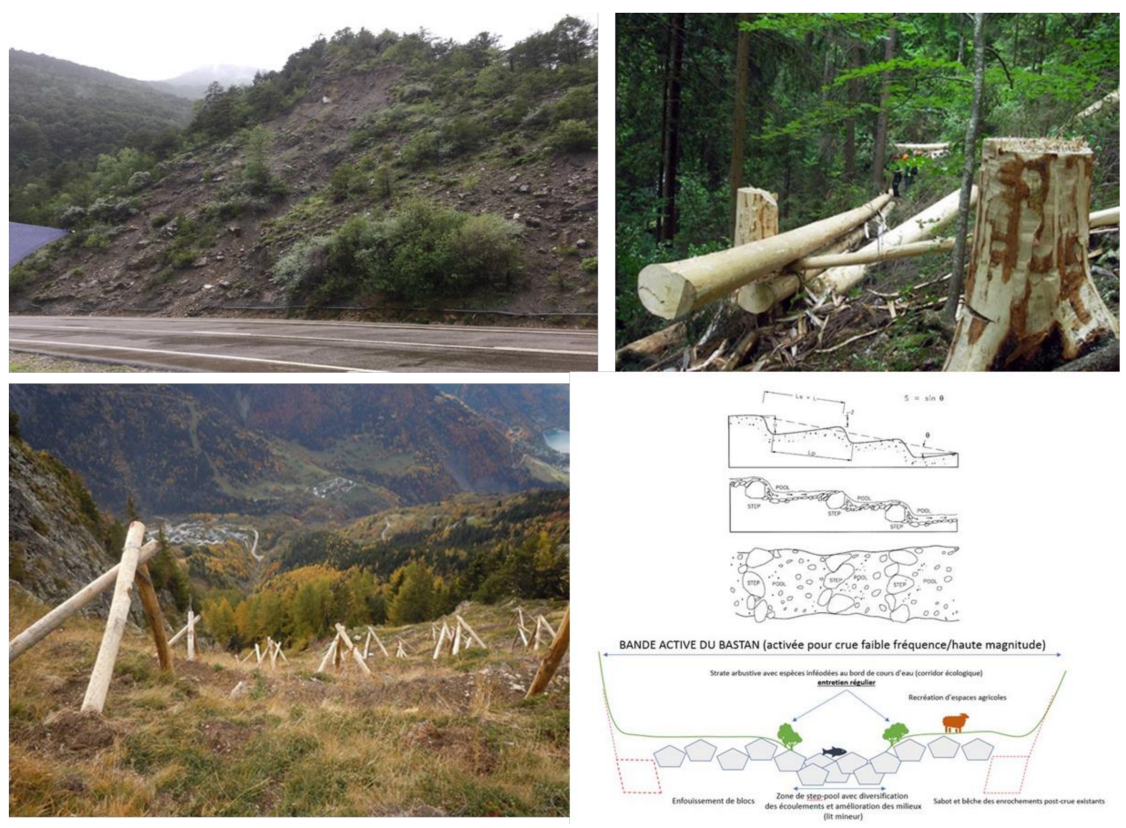

Figure 9. Sites and examples of Pyrenees NBS interventions. Upper left: the till slope at St. Elena, Spain (photo: A. Solheim). Upper right: example of wooden structures to be implemented near release areas for rockfall at Artouste, France (photo: EGTC Space Portalet). Lower left: wooden structures similar to those planned for the Capet site, to protect plants until they have a stabilizing effect (photo: ONF). Lower right: longitudinal and transverse sections of the intended interventions in the Bastan river (From PLVG). Proposed NBS interventions at Socques are not presented here, as the proposal was withdrawn at an early stage, before detailed plans were made for the site.

The second proposed NBS intervention along the trans-border road was at Socques, France (P2 in Figure 8), where a torrent crosses and frequently affects the road RD-934. The site is located in a national park. The torrent flows through a ravine formed in thick deposits of easily erodible glacial sediments; these are regularly detached and transported downstream, clogging the drainage network and causing overflow and damage to the road. A severe flooding and erosion event in 2013 resulted in about 10,000 $\mathrm{m}^{3}$ of deposits which had to be removed. The proposed measure was a system of check dams to create a more balanced and stepped profile of the stream to reduce the energy of the water and favor controlled deposit of materials for their subsequent removal. The check dams were to be built using local rocks and wood. This intervention was cancelled for various reasons, including restrictions due to the status as a national park, technically challenging implementation works and high probability of insufficiently effective solutions. The decision to cancel was made by the site owners before the NBS implementation was evaluated by the Steering Committee.

Another proposed NBS intervention is under preparation further north along RD-934, near the hydropower dam of Artouste, in the municipality of LaRuns, France (P3 in Figure 8). The road descends in sharp turns from the height of the reservoir level to the base of the dam. This area is a fir tree forest on steep slopes, with several fragmented and unstable rock ledges producing rock falls which may hit the road, causing risk for traffic and damage to the road. A direct hit on a vehicle caused one fatality at the site in 2014. Preventive measures such as fences near the road have been proved insufficient as bouncing rocks have jumped 
over them. The NBS intervention to be implemented at Artouste consists of protective installations built of logs of local wood close to the release areas. These constructions will either prevent release or stop released blocks before they accelerate and reach high energy (Figure 9). These measures are to be combined with proper maintenance of the original forest in the slope as this also serves as a barrier for smaller rocks. The area is on public land owned by the LaRuns municipality but is also within the Pyrenees National Park, placing limits on the level of action in the area, the forest management and the selection of plants. Most of the comments made by the Steering Committee during assessment of the proposal were related to the technical details of the measures. It was considered feasible, but some concerns were raised regarding the time for implementation as well as the risk during the implementation/construction phase.

An NBS proposal for the Bastan valley, France, was proposed by the organization "Pays de Lourdes et des Vallées des Gaves-PLVG" and consisted of two interventions in the municipalities of Sers, Betpouey, Viey, Viella and Sassis in the department of HautesPyrénées (P4 in Figure 8). Both interventions were designed to prevent damage from torrents. The Bastan river is a tributary of the larger Gavernie river.

The first of the two interventions was to construct a step-and-pool profile (Figure 9) along the Bastan river in a roughly $1 \mathrm{~km}$ stretch next to the village of Betpouey (P4, Figure 8). This was to be combined with strengthening and increasing the transitional zone along the river, which would allow more space for the river during floods but avoiding the severe erosion and damage previously experienced. The intention is to further upscale this at a later stage to other parts of the river, although this would not be part of the PHUSICOS project.

The second part of the Bastan valley interventions was to remove a concrete structure, previously built in the confluence zone where the smaller Bastan river meets the bigger Gavernie river near the village of Sassis. The structure forms a point into the river, which prevents natural flow and enhances the flooding problems. This structure was to be replaced by a green barrier, receded 10-12 $\mathrm{m}$ from the river, and by establishing a renewed riparian zone along the river.

Although the comments from the Steering Committee during the evaluation process were generally favorable regarding the feasibility of the proposed interventions and mainly requested further technical details, concerns were raised regarding the implementation plan which included significant stakeholder involvement. Contingency plans were requested. The proposed NBS in the Bastan valley were later cancelled in the PHUSICOS project by the proponent, as there were uncertainties regarding the cost, time for implementation and whether local politicians would reach agreement. In addition, there was a certain skepticism to the effectiveness of the solutions. Although these two interventions will not be carried out, the local stakeholder discussions are of interest for the forthcoming discussion on barriers to NBS.

The fifth NBS sub-project in the Pyrenees, in the forest of Capet, France, was proposed by the French Forest National Office (ONF) and the service of Mountain Terrain Restoration (RTM) in association with the French State represented by the Departmental Direction of the Territories (Hautes-Pyrénées) (P5, Figure 8). The proposed and approved intervention is located further up the Bastan valley, in the north slope of the valley facing the village of Baréges. Snow avalanches released from the upper slopes above Baréges pose a severe threat to the village and have also hit the village several times. Situations with a high avalanche hazard often cause evacuations from parts of the village. The measure to be implemented consists of afforestation with selected tree species built under the protection of wooden tripods (Figure 9). Trees are carefully selected to suit the region and altitude. The tripods will protect the trees until they are high enough (4-5 m) to stabilize the snowpack, and during this initial growth period, the tripods will also have a stabilizing effect. There are several avalanche paths in the area, but the one in which the interventions are implemented was selected based on its topography and soil thickness. The evaluation comments from the Steering Committee were generally positive, with questions mostly related 
to details on the species selected, growth rates, degree of protective capability, the planting techniques and maintenance. The proposed intervention was generally considered feasible within the time frame of the project.

\subsection{NBS Implementation Barriers}

In addition to the implementation of NBS, PHUSICOS is also exploring governance innovation, meaning that governance goes beyond government to involve a network of state and non-state actors (e.g., business, civil society, expert communities) in the process of deciding on and implementing NBS policy [18]. Despite the importance of successful NBS governance models to enable NBS implementation and upscaling, it was found that research on the enablers of and opportunities for NBS implementation is sparse [18]. Studies and reports are primarily focusing on urban NBS (e.g., [1,19-21]), their barriers (e.g., [21,22]) or their potential for climate change adaptation (e.g., $[23,24])$. Additionally, governance criteria are underrepresented in NBS assessment frameworks [25], and little research has been conducted on the factors required for successful NBS design and implementation for disaster risk reduction (DRR) in rural and mountain areas [26].

A recent study derived results from an interdisciplinary and transdisciplinary workshop with experts from research, municipalities, policy and society [23]. Among other aspects of NBS, they explored existing barriers and potential opportunities for increasing the scale and effectiveness of nature-based solutions implementation in urban settings. They identified five main categories of barriers and presented these in a "barrier circle" surrounded by opportunities (Figure 10).

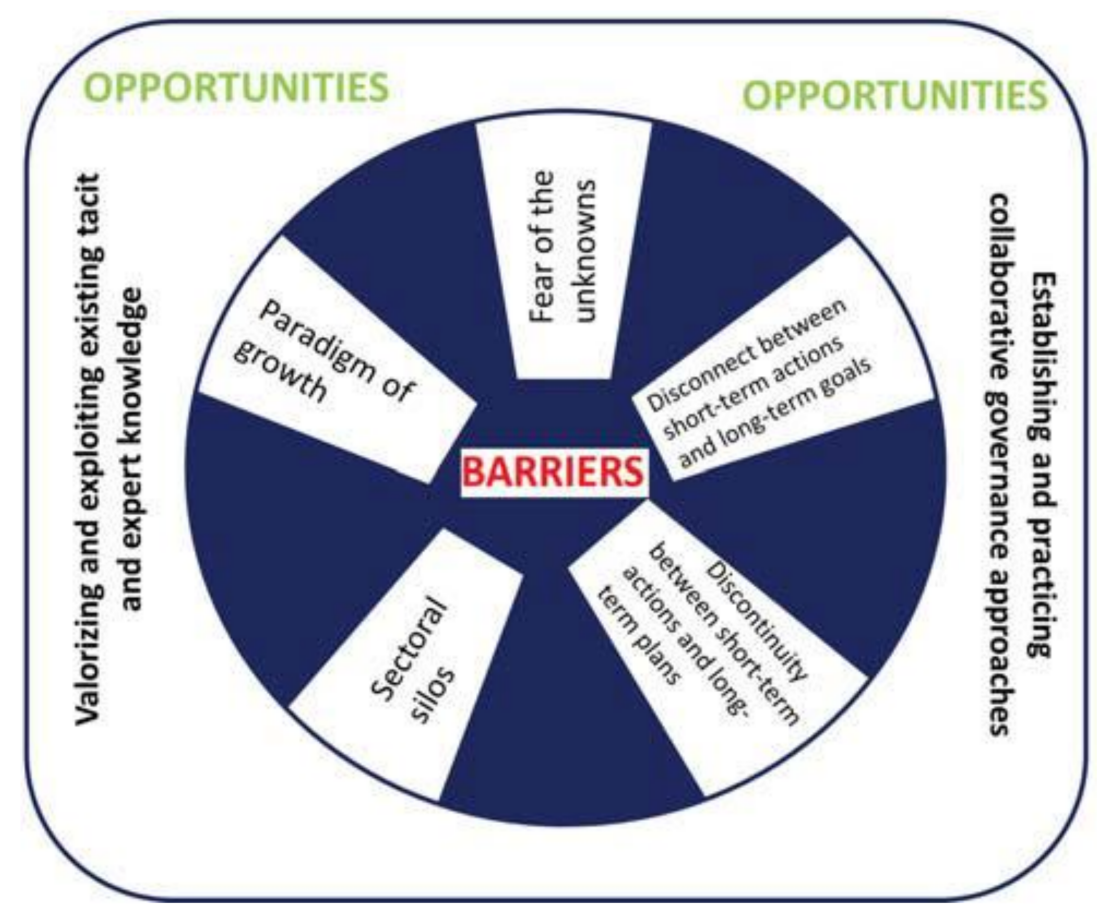

Figure 10. Combination of barrier circle and opportunities that facilitate action for NBS in urban areas [23].

Key enablers and barriers for NBS, both in rural and urban settings, were analyzed and individuated in a review of published research papers on this topic [1]. A selection procedure was used to identify 41 relevant papers for analysis. The review resulted in an assessment of NBS definitions, implementation objectives and main stakeholder groups, as well as concluding with a list of six main classes of barriers and nine enablers. In a new paper, this was increased and diversified further into 15 classes of barriers based on an analysis of the published literature and expert interviews, ranked through a questionnaire and further analyzed using interpretive structural modeling (ISM) [22]. 
The 15 classes of barriers of [22] are presented in Table 2 along with two additional classes of barriers that we have experienced in PHUSICOS. This classification is subsequently used for describing and classifying the barriers experienced in the first 2.5 years of the PHUSICOS project. The column headings in Table 2 denote the main type of barrier for each PHUSICOS example, but several of the challenges experienced in the project relate to more than one of the classes of barriers identified by Sarabi et al. [22]. These barriers have resulted in both delays of implementation and full cancellation of planned interventions.

Table 2. Barriers for the implementation of NBS. Nos. 1-15 are from [22]. Nos. 16 and 17 are based on PHUSICOS experiences. Challenges may relate to more than one potential barrier. Bold text marks the barrier considered most important for each example.

\begin{tabular}{cccc}
\hline & Barriers & PHUSICOS NBS Sub-Project & Comment \\
\hline 1 & $\begin{array}{c}\text { Lack of political will and long-term } \\
\text { commitment }\end{array}$ & Bastan Valley, Pyrenees, France; & Potential lack of will after local elections. \\
\hline 2 & $\begin{array}{c}\text { Lack of sense of urgency among } \\
\text { policymakers }\end{array}$ & Jorekstad, Gudbrandsdalen, \\
Norway
\end{tabular}

3 Lack of public awareness and support

All sites

Public awareness of the problem(s) but not of NBS as a viable solution.

\begin{tabular}{cccc}
\hline 4 & Risk aversion and resistance to change & Bastan Valley, Pyrenees, France; & \\
\hline 5 & Silo mentality & No yet experienced in PHUSICOS \\
\hline 6 & $\begin{array}{c}\text { Misalignments with short-term plans and } \\
\text { long-term goals }\end{array}$ & $\begin{array}{c}\text { Jorekstad, Gudbrandsdalen, } \\
\text { Norway }\end{array}$ & Jorekstad: the merger between counties \\
\hline 7 & $\begin{array}{c}\text { Lack of supportive policy and legal } \\
\text { frame works }\end{array}$ & $\begin{array}{c}\text { Skurdalsåa, Gudbrandsdalen, } \\
\text { Norway }\end{array}$ & \\
& & a
\end{tabular}

8 Lack of design standards and guidelines for maintenance and monitoring

No yet experienced in PHUSICOS

Inadequate knowledge of NBS and, in particular, their co-benefits
9 Lack of skilled knowledge brokers and training programs

$10 \quad$ Functionality and performance uncertainties
All sites

Jorekstad, Gudbrandsdalen,

Norway;

Socques, Pyrenees, France;

Bastan Valley, Pyrenees, France;

Jorekstad, Gudbrandsdalen,

Norway;

Bastan Valley, Pyrenees, France;

\section{Jorekstad, Gudbrandsdalen,}

Norway;

Jorekstad, Gudbrandsdalen, Norway;

Jorekstad, Gudbrandsdalen, Norway;

14 Property ownership complexities

Serchio River Basin (SRB), Italy; Socques, Pyrenees, France;

\begin{tabular}{ccc}
\hline 15 & Space constraints \\
& Procurement & Jorekstad, Gudbrandsdalen, \\
& Norway; \\
& Bastan Valley, Pyrenees, France;
\end{tabular}

17 Other factors Gudbrandsdalen, Norway;

SRB: some discussion regarding the land needed for the sedimentation basin. Not yet experineced in PHUSICOS 


\subsection{Lack of Political Will and Long-Term Commitment}

Municipalities in rural settings are often small, and local administrations have limited personnel resources, resulting in individuals having multiple responsibilities. In such settings, co-creation and co-design in close dialogue with stakeholders are extremely important to avoid skepticism which may seriously affect the project. It is also important to be aware of potential changes in the administration, e.g., in connection with upcoming elections, and to involve the entire political level in the NBS project independent of a political platform.

PHUSICOS experienced two examples where regional and local politics affected the decision-making process. In the Bastan valley project, an additional factor, which eventually made the proponents call off the NBS plans, was the upcoming local elections and the prospect of changing the local government to one less in favor of NBS and also with less knowledge of PHUSICOS and the planned interventions. In addition, it was of course unfortunate that the timing matched with elections, as skeptical stakeholders are also skeptical voters. Together, the two interventions along the Bastan river constituted the largest of the proposed NBS interventions in the Pyrenees, and it is important to learn from what caused the full cancellation of the plans. A closer involvement with the local and regional administration as well as other relevant stakeholders, such as farmers, over a longer time span prior to the planned implementation could have been one way to avoid the situation.

\subsection{Lack of Sense of Urgency Among Policymakers}

In Norway, a major governmental reform including the merging of counties has affected the progress of PHUSICOS NBS implementations. Oppland County was merged with the neighboring Hedmark County to form Innlandet County from January 2020. This change affected PHUSICOS' partner, the Oppland County Administration, which now, as part of the new Innlandet County Administration, faced massive amounts of extra work related to the merger, including establishing new headquarters, redefining roles and setting priorities. Although this was not the main challenge for the implementation of the approved intervention at Jorekstad, the new priorities may have added to the delay in the progress for Jorekstad and also affected the progress of new NBS proposals to PHUSICOS.

\subsection{Lack of Supportive Policy and Legal Frameworks}

The measure proposed for the tributary river Skurdalsåa in the Norwegian demonstrator case site Gudbrandsdalen is the improvement of a small retention dam. This measure falls under the Norwegian regulations for dam classification, potentially invoking a framework of regulations for management and inspection. Norwegian dams are classified in five classes (0-4), with increasing safety requirements for higher classifications. All classes except the lowest (0) require annual reviews including physical inspections. This will have a high annual cost to be carried by the dam owner. The owner at this site is a small private association comprising the local landowners (farmers) along the river and the lake, and this association cannot cover the annual inspection costs. The implication of this is that the measure will not be implemented if the re-vitalized dam is classified as anything other than a "Class 0 dam". There are hundreds of similar dams in the catchments in Gudbrandsdalen and other Norwegian valleys, most built 100-200 years ago. A successful project in Skurdalsåa would have great potential for upscaling to include similar dams. Hence, regulations made for modern dams mainly for hydropower purposes are not suited for regulating small adjustments (often improvements) of the existing small dam, which if updated could provide efficient flood retention without the necessity of large new measures downstream.

\subsection{Lack of Public Awareness and Support}

The skepticism experienced in PHUSICOS can, for a large part, be ascribed to a lack of knowledge: about NBS as effective mitigation measures, but also regarding the potential 
co-benefits of NBS. Co-benefits are an important evaluation criterion for the internal evaluation of interventions to be implemented in PHUSICOS. This type of skepticism is a key factor also for other classes of barriers, including landowner reluctance and local politics. Skepticism may also result from "over-selling" NBS as the only viable solution. It is important to accept that NBS may not be the right solution for all climate-induced hazards and that both traditional solutions and hybrid solutions may be the right solution in some cases. In PHUSICOS, we have experienced skepticism as a component in several of the challenges we have faced, and while this skepticism may not be the single key factor delaying or cancelling the intervention, it certainly affects the processes towards implementation. Examples of skeptical stakeholders include landowners at Jorekstad, as well as landowners, administration and politicians in the case of the planned Bastan valley interventions.

\subsection{Property Ownership Complexities}

PHUSICOS' NBS interventions are planned on both public and private land. This leads to both challenges and possibilities, and examples prove the importance of enthusiasm and a sense of ownership from the landowners' side, whether these are private or public. It also demonstrates the importance of knowledge. All three of these aspects: enthusiasm, sense of ownership and knowledge, can be improved through close stakeholder involvement from the early stage, through co-creation and co-design, often also co-defining and agreeing on the problems to solve.

In the Serchio River Basin demonstrator case site by Lake Massaciuccoli, the organization responsible for the NBS interventions at the site, Autorità di Bacino del Fiume Serchio-ADBS, has had close interaction with farmers and their organizations. This has resulted in availability of necessary land for the two sets of vegetated buffer strips along the irrigation canals. The landowners also offer personnel and machinery for the implementation of the measures. Furthermore, ADBS receives increased interest from other farmers to have similar measures implemented on their land. The projects therefore see a great potential for upscaling in this area.

At the Norwegian demonstrator site in the Gudbrandsdalen valley, the land to be affected by the receded flood barrier at Jorekstad is private. Initially, the affected farmers were generally positive. However, the public hearing of the new land use plan for the area resulted in numerous comments and requirements. Many of these were relevant and useful comments on the technical solutions and their effect, but some were based on economic motives including, for example, compensation claims. Yet others were caused by a lack of knowledge on NBS and skepticism on whether this will reduce the flood risk as well as, or better than, the traditional "gray" measures. Lack of knowledge around NBS' co-benefits is particularly pertinent. In fact, current flood risk management is adopting machine learning for detection of flood susceptibility and inundation areas [27], and flood decision support tools help decision-makers to select the optimal traditional mitigation measure, still without including NBS.

In the Pyrenees demonstrator case site, the approved NBS interventions include both private and public land. In the cancelled case in the Bastan valley, skepticism regarding the effectiveness of the NBS interventions from landowners was comparable to the experience from Jorekstad. This added yet another reason as to why the interventions were called off. In addition, some of the publicly owned areas in the Pyrenees sites are national parks. The proposed and approved measures at Socques were called off partly because of doubt regarding their effectiveness in reducing the risk from torrents, but also because their location in a national park placed serious limitations on the level of interventions allowed. The forest of Capet is also part of a national park. The NBS intervention for this location is afforestation to prevent release of snow avalanches. The national park status put limitations on the implementation activities, such as helicopter traffic and the use of heavy machinery. However, this has been solved and the implementation is well underway, keeping within the allowed level of activities. For the interventions in the Capet forest, the attitude among 
all stakeholders, from the inhabitants to the political level, was generally positive, as the existing measures did not reduce risk sufficiently and were more environmentally intrusive than the proposed NBS.

\subsection{Time Needed for Public Procurement}

Most European countries align with general rules for public procurement within the EU. However, some countries have additional regulations including threshold values and types of activities. Norway, as a non-EU member, has its own regulations regarding public procurement. Common for all is that the procurement documents need to be carefully prepared, the protocols must be followed and the process itself takes time. For example, in Norway, certain time intervals must be given from the call for tenders to the deadline for bids. Then, time is required for evaluation of bids and announcing the winner, followed by usually two weeks' time for potential complaints. The whole process will take at least 2-3 months if the process goes smoothly. Complaints delay the whole process, and if the complaint is based on formal errors in the tender documents or in the selection process, then the procurement process must start over.

At Jorekstad in Gudbrandsdalen, one of the bidders of the competition for the detailed design of the receded flood barrier at Jorekstad complained after the winning bidder had been selected. The competition did not have to be re-announced, but the process of handling the complaint according to the protocol took another 2 months, although the final result of the competition did not change. Such delays in rural mountainous areas are particularly critical as the seasons for implementing measures on-site may be short. Delays of 2-4 months may in fact cause a one-year delay because of missed construction seasons. This is also the case in the Pyrenees where the season for physical work on-site is short. Timing of the procurement process is essential to avoid delays of up to one year.

One of the reasons for the cancellation of the challenges faced in the Bastan valley in the Pyrenees was the expected time delay from the call for tenders to implementation. In the case of EU-funded projects, such as PHUSICOS, costs registered after the formal project's end cannot be claimed. Therefore, even with a one-year extension of the project, until April 2023, the proponents of the measures against flooding in the Bastan valley concluded that the probability of long delays was too large. This, in addition to local politics and stakeholder skepticism, resulted in the cancellation of this NBS implementation.

\subsection{Other Factors}

Most barriers experienced in the PHUSICOS project are covered by the main classes described above. However, economic reasons may also be a cause for resistance, and not only related to claims for loss of arable land. In the valley of Gudbrandsdalen, the catchment of the river Gudbrandsdalslågen and its tributary rivers drain large areas of glacial tills. This results in severe erosion, which is a problem in itself, but which also leads to transport and deposition of large amounts of sand and gravel. Gravel out-take after flooding events is therefore an important additional income for some landowners along the rivers, and this may cause reluctance to implement flood-reducing measures of any type.

\section{Discussion}

A number of potential barriers for the implementation of NBS have been identified in the literature. The large majority of these are based on urban settings, but many of the same barriers are relevant also for rural areas, as shown by the experiences of the present project.

In PHUSICOS, we grouped the challenges experienced so far in accordance with the barrier classes defined by Sarabi et al. [22] and added one more specific class, "Procurement", and one collective class, "Other factors" (Table 2). However, we experience that several of the challenges relate to more than one cause, and in Table 2, each PHUSICOS example is connected to more than one of the barriers of Sarabi et al. [22]. For instance, the cancellation of the proposed and approved measures to reduce the risk from flooding 
in the Bastan valley is ascribed mainly to the lack of political will and long-term commitment, but additional factors also include lack of public support, risk aversion and resistance to change (more trust in well-known traditional solutions, even if they have failed previously), uncertainty in NBS functionality and perceived high cost. Similarly, the challenges for the Jorekstad site in Norway are mainly suffering from a lack of financial resources, but at the same time, we see few financial incentives in the municipal, regional or even national legislations. The public hearings connected to the new land use plan have also revealed uncertainties and skepticism in the functionality and performance of NBS. The larger-scale national political discussion of reducing the number of counties in Norway through mergers has also affected the progress of the process towards implementation of the proposed NBS.

A common issue, which may be hidden behind many of the above defined barriers, is skepticism caused by a lack of knowledge about NBS and, in particular, their co-benefits. This knowledge gap comprises all relevant actors and stakeholders, such as authorities, landowners, politicians and contractors in the building and construction industry. Longterm planning and thinking are required to see the full effect of co-benefits. Furthermore, long-term monitoring of all effects and of affected people's perception of the measures is needed, which may improve as co-benefits become apparent. At the political level, election periods of typically 4 years also put a constraint on the long-term planning. To see the full effect of co-benefits may require a longer time than this.

To overcome skepticism, sharing of experience and knowledge between groups with different expertise and experiences is important. This was also identified as an important activity by Wamsler et al. [28] in their paper on strategies for overcoming NBS barriers. The effect of knowledge sharing from different groups was emphasized as very important, particularly in the context of NBS, where institutional knowledge is generally very limited [28]. Their study was based on urban settings in Swedish cities, but the findings are also applicable to rural settings, as seen by the experiences of the PHUSICOS project.

Furthermore, avoiding "over-selling" NBS as the only viable solution to reduce the risk from hydrometeorological hazards may also help overcome skepticism. A significant portion of NBS interventions require engineering to various degrees and may therefore also be classified as hybrid solutions. A classification scheme for NBS divided this in three types, from Type 1 with low human intervention, to Type 3 with high human intervention [4]. The receded flood barrier at Jorekstad would, for instance, classify as Type 3, whereas the buffer strips in the Serchio River Basin case would be a Type 2 intervention. An important point of Martin et al. [4] is also that the vast majority of NBS require ongoing maintenance. The acceptance of these facts when advocating NBS to policymakers and other stakeholders may also be a means to meet skeptics and increase knowledge.

The issue of supportive policy and legal frameworks affects the planned measures in Skurdalsåa, Norway, negatively as it, until now, has created uncertainty around whether the measure can be carried through to implementation. In Norway, on the other hand, the Norwegian Environment Agency has issued regulations which require NBS to be considered when mitigation measures for natural hazards are being planned. Furthermore, if NBS is not chosen, this has to be justified [29]. This is clearly a step in the right direction and will, if it becomes known and gets used, form an incentive for change towards NBS.

The challenges regarding procurement experienced by PHUSICOS are somewhat different from the main challenges described for urban areas by Maciulyté and Durieux [30]. Based on nine case studies from European cities, a number of challenges experienced and solved by the procurers are pointed out [30]. The issue of time for the procurement process is touched upon, but most of the challenges relate to difficulties finding enough skilled and experienced bidders, as well as obtaining enough citizen involvement, enthusiasm and ownership for the solutions. These issues align with several of the barriers identified by Sarabi et al. [1] and Sarabi et al. [22], such as barriers 3 and 8 in Table 2. An approach that could help to overcome procurement process barriers can be found in the concept of "innovative partnerships" used in a case study from Fredriksberg, Denmark [30]. This is 
a model which may trigger innovation and also speed up the total procurement process. It consists of a competitive phase where suitable partners are selected, followed by an R\&D phase where the innovative solutions are developed in collaboration with the contracting authority. This is again followed by the commercial phase where the selected partner provides the final product. This means that the new solutions can be purchased directly at the end of the process without the need for further procurement to upscale the preferred solution.

The analyses of NBS in urban settings concluded that political, institutional and knowledge-related barriers are the most dominant barriers to successful NBS implementation [22]. We see that the barriers experienced in the rural settings of the PHUSICOS demonstration sites result from the same main mechanisms, including institutional factors, resistance among stakeholders and technical and economic issues.

Success stories which can be used to promote NBS against landslides and flooding in rural areas are generally scarce, but despite the challenges emphasized in this paper, we are confident that the PHUSICOS project will create success stories. The afforestation interventions in the Capet forest are progressing according to plans, as are the interventions in Italy, where an increasing number of farmers around Lake Massaciuccoli are showing interest in the measures. Despite some delays as described above, NBS activities will also be implemented during the course of the project and will be monitored for both benefits and co-benefits through the project period and after, following a comprehensive evaluation framework developed in the project [31].

Despite this study being relatively limited in scope, and with limitations in the procedures for selection of case sites as described in Chapter 2, our main findings are, to a large degree, in line with other published studies of barriers and enablers for NBS implementation despite most of these being in urban settings. We believe it is of importance for the NBS community that these barriers are identified, shared and addressed properly for all relevant settings.

\section{Conclusions}

The PHUSICOS project is a 5-year Innovation Action, funded by the EU under the Horizon 2020 program. The main objective of the project is to demonstrate the effectiveness of NBS and their ability to reduce the impacts from small, frequent events (extensive risks) in rural mountain landscapes. NBS interventions are being implemented in three large-scale demonstrator case sites in Italy, Norway and the French and Spanish Pyrenees. All proposed NBS interventions are evaluated after a set of criteria by the project's Steering Committee before approval for implementation. During the implementation phase, the project experienced several barriers, which either delayed or rendered impossible the implementation of NBS. This paper focuses on the experienced barriers.

A common denominator for the experienced and reported barriers to NBS implementation is a lack of knowledge leading to skepticism. In particular, the advantage NBS have over other adaptation strategies in their ability to deliver multiple benefits is too poorly known among all relevant stakeholder groups. Based on the challenges experienced in the PHUSICOS project, the following conclusions may be drawn on barriers for implementation of NBS in rural settings:

- All relevant stakeholder groups must be involved at an early stage. This may also include co-defining the problem that requires mitigation. Private and public landowners are among the most important groups, as are the local and regional administrative and political levels.

- Adequate time and resources must be spent on explaining the co-benefits. If possible, try to quantify the real value of the co-benefits over time.

- Relevant success stories form a valuable tool in the dialogue with the stakeholders. In PHUSICOS, the Isar river case is presently such a success story (e.g., [32]). 
- NBS should not be "over-sold". To acknowledge that both traditional "gray" solutions and various types of hybrid solutions are viable solutions in many cases, and sometimes the only solution, may also be a means to meet skepticism.

- Educational material and information meetings with stakeholders can fill knowledge gaps. Construction companies should be included, as they are most often involved in the practical construction of NBS.

- Time for proper procurement must be allowed in the planning. Innovative procurement, such as the example from Denmark [30], should be considered if possible.

- Carefully investigate all rules and regulations which apply and what approvals are required. Application procedures may take time and delay the project significantly. Protected areas such as national parks may pose particular challenges.

- A comprehensive quality assurance of all suggested measures by a broad range of experts is important. In PHUSICOS, the Steering Committee formed the QA body, and a more careful following-up of comments, concerns and recommendations from the evaluation process might have helped in lowering some of the barriers.

Although these conclusions are limited by only being based on the PHUSICOS project in its present phase, we believe the above points may serve as "lessons learned" and therefore be of value in overcoming NBS implementation barriers in forthcoming projects.

Author Contributions: Conceptualization, A.S., A.O., V.C. and B.K.; methodology, A.S., A.O., V.C. and B.K.; validation, A.S., A.O., V.C. and B.K.; formal analysis, A.S.; investigation, A.S., A.O., V.C., B.K., T.W.-K., M.O., N.D.S., I.A. and E.G.B.; resources, A.S., A.O., V.C., B.K., T.W.-K., M.O., N.D.S., I.A. and E.G.B.; writing-original draft preparation, A.S.; writing-review and editing, A.S., A.O., V.C., J.M.S. and B.K.; project administration, A.O.; funding acquisition, A.O. and B.K. All authors have read and agreed to the published version of the manuscript.

Funding: The PHUSICOS project has received funding from the European Union's Horizon 2020 research and innovation program under grant agreement No. 776681.

Institutional Review Board Statement: Not applicable.

Informed Consent Statement: Not applicable.

Data Availability Statement: Data sharing not applicable. No new data were created or analyzed in this study. Data sharing is not applicable to this article.

Acknowledgments: Information on the three demonstrator case sites was provided from the Innlandet County Administration, Norway, the Autorità di Bacino del Fiume Serchio (ADBS), Italy, and the Consorcio de la Communauté de Travail des Pyrénées (CTP), Spain and France. Three anonymous reviewers gave valuable comments and helped in improving the manuscript.

Conflicts of Interest: The authors declare no conflict of interest. The funders had no role in the design of the study; in the collection, analyses, or interpretation of data; in the writing of the manuscript, or in the decision to publish the results.

\section{References}

1. Sarabi, S.; Han, Q.; Romme, A.G.L.; De Vries, B.; Wendling, L.A. Key Enablers of and Barriers to the Uptake and Implementation of Nature-Based Solutions in Urban Settings: A Review. Resources 2019, 8, 121. [CrossRef]

2. Cecchi, C. Towards an EU Research and Innovation Policy Agenda for Nature-Based Solutions E Re-Naturing Cities: Final Report of the Horizon 2020 Expert Group on Nature-Based Solutions and Re-Naturing Cities; 10.2777/479582; Directorate-Generale for Research and innovation, European Commission: Brussels, Belgium, 2015.

3. European Commission. Nature-Based Solutions and How the Commission Defines Them, Funding, Collaboration and Jobs, Results and Publicatuions. Available online: https:/ / ec.europa.eu/info/research-and-innovation/research-area/environment/ nature-based-solutions_en (accessed on 20 October 2020).

4. Martín, E.G.; Costa, M.M.; Máñez, K.S. An operationalized classification of Nature Based Solutions for water-related hazards: From theory to practice. Ecol. Econ. 2020, 167, 106460. [CrossRef]

5. Ruangpan, L.; Vojinovic, Z.; Di Sabatino, S.; Leo, L.S.; Capobianco, V.; Oen, A.M.P.; McClain, M.E.; Lopez-Gunn, E. Nature-based solutions for hydro-meteorological risk reduction: A state-of-the-art review of the research area. Nat. Hazards Earth Syst. Sci. 2020, 20, 243-270. [CrossRef] 
6. Chausson, A.M.; Turner, B.; Seddon, D.; Chabaneix, N.; Girardin, C.A.J.; Kapos, V.; Key, I.; Roe, D.; Smith, A.; Woroniecki, S.; et al. Mapping the effectiveness of nature-based solutions for climate change adaptation. Glob. Chang. Biol. 2020, 6134-6155. [CrossRef]

7. Bernardi, A.; Enzi, S.; Mesimaki, M.; Lehvavirta, S.; Jurik, J.; Kolokotsa, D.; Gobakis, K.; van Rompaey, S.; Goni, E.; Mink, E.; et al. Barriers Landscape and Decision Making Hierarchy for the Sustainable Urbanisation in Cities via NBS; H2020 ThinkNature, Deliverable D5.1; 2019; p. 197. Available online: https://platform.think-nature.eu/system/files/project_deliverable/d5.1_0.pdf (accessed on 10 December 2020).

8. Pugliese, F.; Caroppi, G.; Zingraff-Hamed, A.; Lupp, G.; Giugni, M. Nature-Based Solutions (NBSs) Application for HydroEnvironment Enhancement. A Case Study of the Isar River (DE). Environ. Sci. Proc. 2020, 2, 30.

9. Haselberger, S.; Ohler, L.-M.; Junker, R.; Otto, J.-C.; Glade, T.; Kraushaar, S. Quantification of biogeomorphic interactions between small-scale sediment transport and primary vegetation succession in the Gepatschferner glacier foreland, Austria. Earth Surf. Process. Landf. under review.

10. Solheim, A. Procedures for Distribution of Funds and Tenders. H2020-PHUSICOS Deliverable D2.1, 2018, 46pp. Available online: https:/ / phusicos.eu/wp-content/uploads/2019/01/D2_1_Procedures_Rev1_Procedures-for-distribution-of-funds-andtenders_final.pdf (accessed on 30 November 2020).

11. Solheim, A.; Capobianco, V. Overview of Submitted and Approved NBSs for Implementation during Months 1-14. H2020PHUSICOS Deliverable D2.2, 2019, 30pp. Available online: https://phusicos.eu/wp-content/uploads/2019/01/D2_2_Rev-1_ Overview-of-submitted-and-approved-NBSs-months-1-14_final.pdf (accessed on 30 November 2020).

12. Oppland County Administration. Regional Master Plan for the Gudbrandsdalslågen and Its Tributaries; Measures to Reduce Damage from Flooding and Landslides. Available online: https://innlandetfylke.no/_f/p1/i34056176-b265-41c3-a53b-e63f4b9 ab5cb/lagen-plan_english_main-document.pdf (accessed on 25 November 2020).

13. Norwegian Environment Agency. Maps of Nature Types. Available online: https:/ / kart.naturbase.no/ (accessed on 25 October 2020).

14. Silvestri, N.; Pistocchi, C.; Antichi, D. Soil and Nutrient Losses in a Flat Land-Reclamation District of Central Italy. Land Degrad. Dev. 2016, 28, 638-647. [CrossRef]

15. Stokes, A.; Norris, J.E.; Van Beek, L.P.H.; Bogaard, T.; Cammeraat, E.; Mickovski, S.B.; Fourcaud, T. How vegetation reinforces soil on slopes. In Slope Stability and Erosion Control: Ecotechnological Solutions; Springer: Dordrecht, The Netherlands, 2008; pp. 65-118.

16. Capobianco, V.; Cascini, L.; Cuomo, S.; Foresta, V. Wetting-drying response of an unsaturated pyroclastic soil vegetated with long-root grass. Environ. Geotech. 2020, 1-19. [CrossRef]

17. Foresta, V.; Capobianco, V.; Cascini, L. Influence of grass roots on shear strength of pyroclastic soils. Can. Geotech. J. 2020, 57, 1320-1334. [CrossRef]

18. Martin, J.; Bayer, J.; Liu, W.; Scolobig, A.; Balsiger, J. NBS in-Depth Case Study Analysis of the Characteristics of Successful Governance Models. PHUSICOS Deliverable D5.1, 2019. Available online: https://phusicos.eu/wp-content/uploads/2020/10/ D5_1_NBS-in-depth-case-study-analysis_Final.pdf (accessed on 10 December 2020).

19. Raymond, C.M.; Frantzeskaki, N.; Kabisch, N.; Berry, P.; Breil, M.; Nita, M.R.; Geneletti, D.; Calfapietra, C. A framework for assessing and implementing the co-benefits of nature-based solutions in urban areas. Environ. Sci. Policy 2017, 77, 15-24. [CrossRef]

20. Somarakis, G.; Stagakis, S.; Chrysoulakis, N. Thinknature Nature-Based Solutions Handbook. ThinkNature Project Funded by the EU Horizon 2020 Research and Innovation Programme 2019. Available online: https:/ / platform.think-nature.eu/content/ thinknature-handbook (accessed on 18 November 2020).

21. Schmalzbauer, A. Barriers and Success Factors for Effectively Cocreating Nature-Based Solutions for Urban Regeneration. Deliverable 1.1.1. Available online: https://clevercities.eu/fileadmin/user_upload/Resources/D1.1_Theme_1_Barriers_success_ factors_co-creation_HWWI_12.2018.pdf (accessed on 15 November 2020).

22. Sarabi, S.; Han, Q.; Romme, A.G.L.; De Vries, B.; Valkenburg, R.; Ouden, E.D. Uptake and implementation of Nature-Based Solutions: An analysis of barriers using Interpretive Structural Modeling. J. Environ. Manag. 2020, 270, 110749. [CrossRef]

23. Kabisch, N.; Frantzeskaki, N.; Pauleit, S.; Naumann, S.; Davis, M.; Artmann, M.; Haase, D.; Knapp, S.; Korn, H.; Stadler, J.; et al. Nature-based solutions to climate change mitigation and adaptation in urban areas: Perspectives on indicators, knowledge gaps, barriers, and opportunities for action. Ecol. Soc. 2016, 21. [CrossRef]

24. Kuban, B.; Demir, E.; Emir, K.; Tabanoğlu, O. H2020-URBAN GreenUP, Deliverable D1.5, 2018, 69pp: Barriers and Boundaries Identification, 2018. Available online: file:/ / C:/Users/as/Downloads/urban_greenup_d1.5_barriers_boundaries.pdf (accessed on 10 December 2020).

25. Sekulova, F.; Anguelovski, I. The Governance and Politics of Nature-Based Solutions. Available online: https://naturvation. eu/sites/default/files/news/files/naturvation_the_governance_and_politics_of_nature-based_solutions.pdf (accessed on 26 December 2020).

26. Accastello, C.; Blanc, S.; Brun, F. A Framework for the Integration of Nature-Based Solutions into Environmental Risk Management Strategies. Sustainability 2019, 11, 489. [CrossRef]

27. Islam, A.R.M.T.; Talukdar, S.; Mahato, S.; Kundu, S.; Eibek, K.U.; Pham, Q.B.; Kuriqi, A.; Linh, N.T.T. Flood susceptibility modelling using advanced ensemble machine learning models. Geosci. Front. 2021, 12, 101075. [CrossRef]

28. Wamsler, C.; Wickenberg, B.; Hanson, H.; Alkan-Olsson, J.; Stålhammar, S.; Björn, H.; Falck, H.; Gerell, D.; Oskarsson, T.; Simonsson, E.; et al. Environmental and climate policy integration: Targeted strategies for overcoming barriers to nature-based solutions and climate change adaptation. J. Clean. Prod. 2020, 247, 119154. [CrossRef] 
29. Norwegian Environmental Agency. (In Norwegian). Available online: https://www.miljodirektoratet.no/myndigheter/ klimaarbeid/klimatilpasning/veiledning-til-statlige-planretningslinjer-for-klimatilpasning/vurdere-naturbaserte-losninger/ (accessed on 10 December 2020).

30. Maciulytè, E.; Durieux, E. Public Procurement of Nature-Based Solutions. Addressing Barriers to Procurement of Urban NBS: Case Studies and Recommendations; Directorate-General for Research and Innovation, European Commission: Brussels, Belgium, $2020 ;$ p. 45. ISBN 978-92-76-21601-8.

31. Autuori, S.; Caroppi, G.; De Paola, F.; Giugni, F.; Pugliese, F.; Stanganelli, M.; Urciuoli, G. Comprehensive Framework for NBS Assessment. PHUSICOS Deliverable D4.1. Available online: https://phusicos.eu/wp-content/uploads/2019/05/D4.1_Task4.1 _UNINA_14052019_Final_withAppendicies.pdf (accessed on 15 November 2020).

32. Mahida, N. Great (un) expectations: The Isar-Plan in Munich. Presented at the European River Restoration Conference, Vienna, Austria, 11-13 September 2013. 